\title{
ÉCFRASE E O PALCO: TEATRALIDADE E RECEPÇÃO
}

\author{
Ruth WeBB*
}

Université de Lille 3

\begin{abstract}
Resumo. Para a teoria antiga, uma das características da écfrase - e do conceito afim da enargeia - é sua natureza teatral. A analogia com o palco está presente no objetivo expresso da écfrase ("transformar ouvintes em espectadores"), assim como seu uso é associado a contextos em que o emissor é concebido como participante de uma performance ao vivo diante de uma audiência. Este artigo trata das implicações da écfrase como performance para nossa leitura de uma série de textos, dando atenção especial para o uso de uma linguagem vívida na tragédia clássica, na qual as imagens evocadas pela fala do mensageiro existem em conformidade com a visão real do palco. Leitores de séculos posteriores parece que estavam conscientes desse efeito e de seus paradoxos, como sugere a presença, entre as Imagines de Filóstrato, de diversas cenas inspiradas em falas de mensageiros de tragédias, apresentadas como se fossem os motivos das pinturas. Portanto, duas formas de recepção devem ser consideradas: a recepção das peças pela audiência ateniense original; e a recepção dos textos dessas mesmas peças pelos leitores em períodos posteriores da Antiguidade.
\end{abstract}

Palavras-chave. Écfrase; performance; tragédia grega; falas de mensageiro; enargeia. D.O.I. 10.11606/issn.2358-3150.v18i1p3-18

Na Etiópica de Heliodoro, um "ROMAnCE" composto No terceiro ou quarto século da era cristã, um personagem, o jovem ateniense Cnêmon, implora a outro por uma descrição de um evento que o faça "ver". Naturalmente, é o relato de uma história de amor, e o narrador interno (o esperto, odisseico, sábio egípcio Kalasiris) estava em vias de ignorar, silenciando-se, o momento da procissão ritual na qual o herói e a heroína se viram pela primeira vez. O entusiasmo de Cnêmon por sensação e espetáculo foi tratado com certo desinteresse por Jack Winkler em seu artigo seminal sobre a estratégia narrativa de Heliodoro. Winkler entende o desejo de Cnêmon de "ver" o relato de Kalasiris como uma leitura fundamentalmente incorreta, que torna confuso o enredo ao ser atendido. A interpretação de Winkler ao romance tem muito de recomendável, mas sua condenação a Cnêmon - apesar de uma estratégia

\footnotetext{
Professora de Grego na Université Charles-de-Gaulle Lille 3 e membro do UMR 8163, "Savoirs, Textes, Langage".

* Artigo recebido em 05.ago.2015 e aceito para publicação em 31.out.2015. O texto não foi revisto desde sua apresentação oral.
} 
retórica efetiva na estrutura de uma argumentação longa e complexa - foi matizada em trabalhos mais recentes sobre Heliodoro por outros estudiosos. ${ }^{1}$ E não poderia ser de outra forma, pois há inúmeras evidências sugerindo que o tipo de apreciação do espetáculo por meio de palavras mostrada pelo personagem, Cnêmon, era um aspecto aceito e respeitado da recepção de textos clássicos no período imperial. Tais efeitos são discutidos nos scholia, manuais de retórica e por Longino em seu tratado Do Sublime sob as denominações de hupotupôsis, enargeia e ekphrasis, sendo essa última o exercício que ensinava os estudantes das escolas retóricas não apenas a maneira de reconhecer e responder a esses efeitos como também criá-los em seus próprios escritos. É evidente que Heliodoro tinha total consciência da conexão entre seu personagem ateniense e as teorias retóricas de seu próprio tempo, uma vez que ele faz Cnêmon utilizar precisamente o mesmo vocabulário usado nas manuais técnicos para descrever os efeitos da ekphrasis e enargeia. Ele se queixa de que Kalasiris ainda não o havia tornado um espectador:

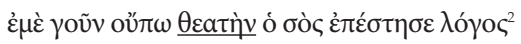

o que podemos comparar diretamente com a função da écfrase conforme descrito nos Progymnasmata, como aqui em Nicolau, o Sofista:

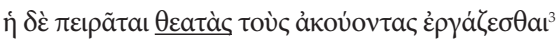

Kalasiris o atende, fornecendo um relato suntuosamente detalhado da procissão e da aparência da heroína naquele momento. Cnêmon o interrompe, reagindo como se pudesse de fato ver (com seus olhos físicos) e não apenas imaginar (com seus olhos da mente) a cena, gritando "São eles!". Após a confusão ser dissipada, Cnêmon explica:

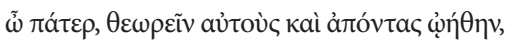

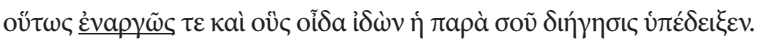

Novamente, ele usa uma linguagem que é muito próxima àquela dos manuais retóricos nos quais a definição de écfrase é:

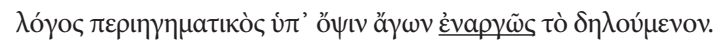

Esse episódio traz à luz muitas questões. Entre elas: recepção e performance. Em um nível, aquele da estória, é uma ilustração do prazer visual a ser obtido em uma performance verbal.

\footnotetext{
${ }^{1}$ Winkler 1982, 139-44.

2 Ver, por exemplo, Morgan 1989 e 1991; Hardie 1998; Hunter 1998.

${ }^{3}$ Heliodoro, Aethiopica 3.1.1.
} 


\section{RESPOSTA IMAGINATIVA COMO REAÇÃO NORMAL A PALAVRAS}

Em seu tratamento desdenhoso a Cnêmon e suas exigências ao narrador, Winkler estava refletindo uma forte tradição da recepção textual moderna. As próprias teorias da recepção enfatizaram o papel ativo do leitor na constituição de significados, mas isso é frequentemente entendido como resposta intelectual, envolvendo atos de interpretação. Certamente, muitos textos antigos (o romance de Heliodoro entre eles) de fato estimulam esse tipo de resposta, mas esse, obviamente, não era o único tipo de recepção esperado por leitores e escritores antigos.

Ao pedir que as palavras do narrador apelem a seus sentidos, Cnêmon representa uma tradição intelectual significante na Antiguidade Pós-Clássica (particularmente no período Imperial). É muito claro, a partir do tipo de comentários que encontramos em críticos e retóricos do período, tais como Longino, Dionísio de Halicarnasso e Quintiliano, bem como nos scholia, que uma resposta imaginativa à evocação de cenas era esperada $\mathrm{e}$ que isso se aplicava a uma ampla variedade de gêneros: tragédia, épica, retórica e historiografia.

Dionísio de Halicarnasso é um dos primeiros a discutir esse efeito da linguagem em seu capítulo sobre Lísias (7), cuja importância para a poética foi destacada pela primeira vez por Graham Zanker em seu artigo: 'Enargeia in the Ancient Criticism of Poetry'. $\mathrm{O}$ crítico augustano fala sobre Lísias:

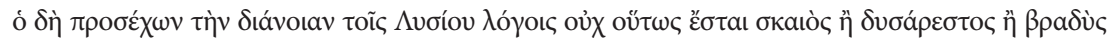

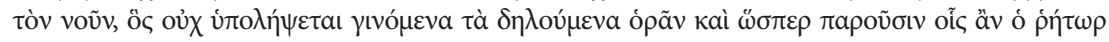

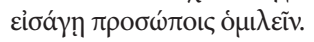

Ninguém pode ser tão desajeitado, difícil de agradar ou intelectualmente lento (skaios, dusarestos kai bradus ton noun) que não sentirá que pode ver o que está sendo demonstrado (ta dèloumena) como se estivesse de fato acontecendo e que está interagindo com os personagens introduzidos pelo orador como se estivessem presentes.

Poderia ser tentador atribuir o desejo do crítico greco-romano de mergulhar imaginativamente de volta à Atenas do quarto século a uma nostalgia pelo passado. Mas, os comentários de Dionísio são parte de uma apreciação técnica dos escritos de Lísias. Além do mais, seus sentimentos encontram eco em Quintiliano no século seguinte, que escreveu em termos semelhantes acerca do impacto do desenho verbal de Verres por Cícero: questiona "existe alguém tão incapaz de ('tam procul abest') formar ima-

\footnotetext{
${ }^{4}$ Nicolau, Prog. 68 (ed. J. Felten).
} 
gens de coisas que não parece ver...?". Pois tanto para Dionísio como para Quintiliano, uma resposta imaginativa era a norma, e a incapacidade de "ver" com os olhos da mente era sinal de uma incapacidade, uma deficiência (abest), a marca dos intelectualmente lentos (bradus) e de caráter difícil (dusarestos).

O personagem ficcional de Heliodoro, Cnêmon, com seu entusiasmo por espetáculos imaginativos que podem ser evocados por palavras está, assim, em muito boa companhia.

A essa lista também podemos acrescentar a observação de Plutarco acerca de Tucídides, que, mais do que ser o epítome do historiador sóbrio e analítico, é uma fonte de sensação e arrebatamento. Ele afirma:

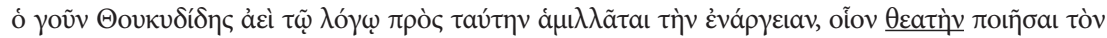

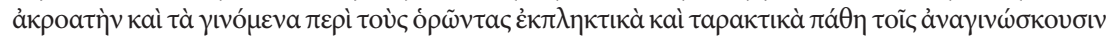

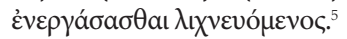

Tucídides está sempre buscando vividez (enargeia) em seus escritos, pois ele deseja intensamente transformar o ouvinte em espectador e produzir nas mentes de seus leitores os sentimentos das emoções de assombro e consternação, experimentados por aqueles que testemunharam os eventos.

Essas são avaliações pragmáticas da recepção que privilegiam o que pode parecer-nos relatos supreendentemente imprecisos e subjetivos da experiência de leitura. Apesar de Quintiliano e Dionísio estarem escrevendo para ajudar outros a compor seus trabalhos, praticamente não há uma análise de como, exatamente, obter esses efeitos. Os tratamentos do exercício de écfrase nos Progymnásmata, i.e. textos escolares, são pouco úteis em termos práticos - seus ensinamentos explícitos são confinados a afirmações vagas e gerais - a parte mais valiosa de seus ensinamentos se encontra na lista de exemplos citada. Estão todos de acordo quanto ao impacto visual de muitas passagens da literatura clássica. 'O que mais alguém veria se estivesse de fato estado presente?' pergunta Quintiliano em uma evocação às orações de Cícero sobre as consequências de uma festa imoral. Longino pergunta, após citar o relato de Heródoto ${ }^{6}$ da viagem entre Elefantina e Meroe:

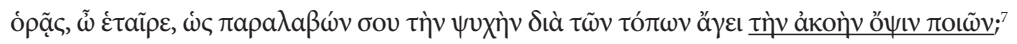

"Você vê como ele se apossa de sua mente e a leva em uma viagem através de todos esses lugares, tornando a audição tão boa quanto a visão?"

\footnotetext{
5 Zanker 1981.

${ }^{6}$ Plu., Mor. 347 A 9 (De Gloria Atheniensum).

${ }^{7}$ Hdt. 2.29.2-6.
} 
Encontramos os únicos indícios práticos acerca da mecânica da visualização na breve menção de Quintiliano sobre sua resposta imaginativa ao retrato verbal de Verres por Cícero. ${ }^{8}$ Isso é extremamente revelador, pois onde Cícero menciona simplesmente as vestimentas de Verres, sua atitude e o fato de estar acompanhado por uma muliercula (uma mulher sem valor), a imagem criada por Quintiliano inclui muitos outros detalhes que devem ser evocados por associação: os outros personagens em volta deles, suas expressões e gestos. É claro, portanto, que a visualização na linguagem é um processo de duas vias envolvendo a participação ativa do ouvinte que responde a certos estímulos verbais formando imagens em sua mente e, então, em um processo ulterior, as suplemente por associação, criando uma versão pessoal dos eventos.

Este é precisamente o modelo mostrado no episódio da Etiópica de Heliodoro com o qual iniciei. A evocação pertence a uma comunicação de duas vias entre dois personagens na qual o receptor avalia e responde ao enunciador com imagens mentais. Na Etiópica, Cnêmon até mesmo dá voz à sua resposta, como vimos, criando um desentendimento que é ao mesmo cômico e um comentário muito sério sobre o efeito da leitura, já que Kalasiris é confundido pela resposta à sua descrição vívida.

Isso me traz à primeira conexão entre meu assunto e performance. $\mathrm{O}$ modo de recepção implicado por todos os relatos de linguagem vívida écfrase, enargeia, hupotupôsis, diatupôsis - é aquele da performance ao vivo, e isso se aplica até mesmo à recepção de textos escritos. O que excita o entusiasmo de Longino na descrição da viagem de Elefantina a Meroe é que ela é feita na segunda pessoa do singular (nem sempre indicada nas traduções modernas). Heródoto diz: “Tu navegarás rio acima a partir de Elefantina, e então chegarás a uma planície. Após cruzá-la, embarcarás em outro navio e navegarás por dois dias" (o que estimula Longino, por sua vez, a apostrofar diretamente seu leitor - "Você vê...?"). Isso indica que o tipo de resposta a textos escritos que encontramos em nossas fontes é modelado sobre a performance retórica ou teatral.

É possível até mesmo argumentar que o modelo de visualização mais influente nas antigas concepções de enargeia e écfrase é aquele do teatro e quando os teóricos enfatizam a necessidade de transformar ouvintes em espectadores a metáfora sugere nem tanto o apreciador de uma pintura (o modelo dominante para o entendimento moderno de écfrase) mas o espectador-Cnêmon deseja ser transformado em um espectador de um evento, uma performance pública: a procissão em Delfos. É possível argumentar que

${ }^{8}$ Quint. Inst. 8.3.64-5.

Let. Cláss., São Paulo, v.18, n.1, p.3-18, 2014 
esse é o significado primário do termo theatês 'espectador' nas definições de écfrase e enargeia. A diferença é de importância vital, pois a analogia entre as audiências de écfrases e o apreciador de uma pintura tende a sugerir que a cena é necessariamente estática. Écfrase, contudo, em oposição às concepções modernas de descrição, podia ser, e frequentemente era, uma sequência de eventos se desenrolando no tempo, como uma peça teatral.

\section{ÉCFRASE E ATOS DE FALA}

Outra conexão com a questão da performance é o fato de que tais passagens são performativas no sentido linguístico, conforme explorado por J. L. Austin, How to do things with words (1962). Austin destaca afirmações como 'Eu vos declaro marido e mulher' na cerimônia de casamento, que não são verdadeiras ou falsas, mas fazem diferença para o mundo. Essa função performativa da linguagem é, assim, diferente de sua função constativa (i.e., sua habilidade em carregar informações que sejam verdadeiras ou falsas). Essa distinção entre usos constativo e performativo da linguagem pode ser aplicada à ecfrase e usos similares que "fazem o ouvinte ver". Da mesma forma que um discurso performativo, écfrase e enargeia envolvem o uso da linguagem para obter um efeito e causar impacto sobre o mundo real, e não para afirmar fatos acerca do mundo.

Os retóricos antigos, portanto, entendiam o uso da visualização em retórica como o que Austin chamaria de "performativo". Os efeitos sobre a realidade são retardados, é verdade. O objetivo é fazer a audiência sentir como se estivesse presente ao próprio evento e então decidir e agir em acordo àquilo que foi dito. $\mathrm{O}$ ato, em um contexto retórico, é normalmente um voto, mas Filóstrato, em Vidas dos Sofistas 582, registra uma anedota sobre Hélio Aristides cuja Carta ao Imperador após a destruição de Esmirna por um terremoto levou Marco Aurélio às lágrimas e, assim, garantiu que ele fornecesse dinheiro para a reconstrução da cidade. Filóstrato cita as palavras exatas que tiveram esse efeito: foi uma metáfora, comparando a cidade devastada a uma terra arrasada através da qual o vento sopra. Isso teve o efeito de criar uma imagem mental de vazio que foi sobreposta à evocação de glórias passadas da cidade. Mesmo se a enargeia não produz, como aqui, uma alteração física no mundo, ela ainda pode provocar uma mudança mais sutil, alterando a disposição da audiência.

Essas duas conexões com o termo "performance" apelam a diferentes usos do termo. As conexões entre écfrase como espetáculo visual que transforma o ouvinte em "espectador" pertencem à performance como espetáculo. 
O sentido de "performance" ativo na segunda definição é o meio para obter algo. Mas, ao final, esses dois sentidos são profundamente imbricados, uma vez que os efeitos da linguagem são espetáculos visuais (performances) que provocam um efeito no leitor, e a consequência disso é que estamos muito longe de um conceito de literatura como um fenômeno puramente estético.

\section{ÉCFRASE, VISÃO E PERFORMANCE POÉTICA}

Essa observação acerca da natureza performativa da écfrase traz à tona a questão do uso de e da resposta $a$ apelos à imaginação em performances de todos os tipos.

Em meu trabalho até o momento, eu me ative a textos retóricos do período imperial, pela simples razão de que esses textos nos falam acerca das definições e funções da linguagem vívida - essencialmente para apelar à imaginação, para uma variedade de efeitos, acima de tudo para comover e, portanto, aumentar a força persuasiva de um discurso. Eles também explicam (nos casos de Quintiliano e Longino) como um orador (ou poeta) consegue esse efeito em termos práticos, mesmo que suas análises linguísticas deixem muito a desejar a partir de nossa perspectiva atual. Quintiliano, por exemplo, fala da necessidade do orador de imaginar a si mesmo na cena que ele traduz nas palavras que a irão transmitir a uma audiência. Longino descreve phantasia como algo que ocorre (tanto na poesia como na prosa):

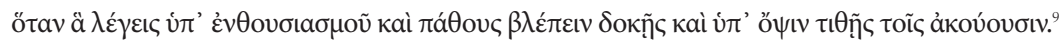

"quando, sob os efeitos da inspiração e da paixão, você parece ver o que está descrevendo e o traz perante os olhos de seus ouvintes".

Em segundo lugar, o discurso retórico é sempre uma performance, pelos motivos mencionados acima: ele assume um contato ao vivo ou quase ao vivo entre um orador e um receptor, não é completo a menos que seja ouvido e é mais frequentemente dirigido a uma audiência particular, em um local e momento particulares. Mas, é claro, muitas dessas observações se aplicam da mesma forma à poesia no contexto antigo: a poesia era em si mesma uma performance, dirigida a um certo público em certo local e momento e tentava obter certos efeitos. Longino pode classificar tais efeitos na poesia como causas da ekplēxis mas podemos desejar ir além, 
muito além, para considerar um caso muito particular, aquele da linguagem vívida na tragédia.

Antes de passarmos à tragédia, via discussão e reflexão de Longino sobre a tragédia em outro texto imperial, Imagines de Filóstrato, é interessante, me parece, e importante observar que a importância da visualização traz o trabalho do retórico do período imperial próximo ao modelo de composição proposto por Egbert Bakker para os poemas homéricos. Escrevendo sobre a importância da deixis que "aponta" para o passado na poesia homérica, Egbert Bakker cita o testemunho de poetas orais modernos que alegam que a visualização era um momento inicial essencial para o processo de composição oral. ${ }^{10}$ Não podemos, é claro, saber se tais práticas se encontram por trás da épica homérica, mas a tese de Bakker é extremamente atraente, considerando-se que o desejo de tornar presente está claramente incorporado à linguagem e é reconhecido por críticos de períodos mais tardios que louvaram o uso homérico da enargeia.

Os efeitos da visualização original do bardo são, assim, ainda perceptíveis no texto e certamente parecem ter sido perceptíveis a audiências secundárias posteriormente na Antiguidade, como podemos perceber no Íon de Platão. Aqui, o rapsodo reconhece sua impressão de estar presente nos eventos que relata, simplesmente por repetir o texto homérico. Sócrates pergunta,

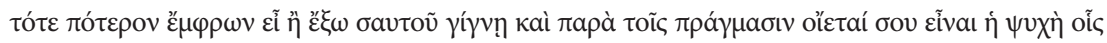

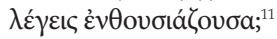

Você está consciente ou fora de si mesmo e sua alma pensa estar em um estado de inspiração e presente naqueles eventos que você relata?

Íon aceita essa afirmação, concordando que esse estado é comunicado aos ouvintes (mesmo se Platão estiver sendo irônico, podemos aceitar que isso reflete em algum grau a forma que as audiências atenienses recebiam sua herança literária).

Existem grandes diferenças entre a função dos apelos à imaginação na poesia arcaica (incluindo-se a lírica) e textos mais tardios. Ainda mais importante, os assuntos evocados na poesia arcaica, sejam os eventos da Guerra de Troia ou os deuses, têm uma realidade e uma significância para a audiência que são distintas dos assuntos seculares da retórica. 


\section{TEATRO}

Um caso particularmente interessante é a tragédia, por duas razões principais: a tragédia é uma das fontes dos efeitos visuais discutidos por Longino, mostrando que leitores mais tardios estavam cientes de seu impacto sobre a imaginação; em segundo lugar, a tragédia é um exemplo particularmente interessante de visualização em performance, considerando-se que as palavras acompanhavam ações reais e personagens reais no palco (em oposição à épica, em que tudo, falas e ações, é criado pela palavra). Se eu busco indícios nas recepções antigas da tragédia clássica, i.e., em comentários encontrados em leitores mais tardios, isso não se dá - é importante assinalar - porque eles são necessariamente superiores aos nossos próprios insights, mas porque fornecem uma via importante para examinar a questão. Esses leitores tardios de tragédia estavam conscientes de que liam textos relacionados a performances. Dião Crisóstomo compara sua situação favoravelmente em relação ao ateniense do período clássico, dizendo que podia ler três Filoctetes - de Ésquilo, Sófocles e Eurípides - ao mesmo tempo, o que ele fazia, e "apreciava o espetáculo":

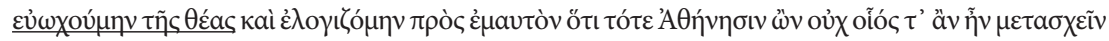

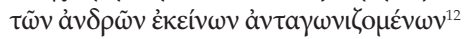

Muitos dos exemplos de phantasia na poesia discutidos por Longino são retirados da tragédia. Notoriamente, ele admira a forma com que o poeta faz o leitor imaginar a presença das fúrias em Orestes não por meio da apresentação no palco (como nas Eumênides de Ésquilo), mas por meio das brevíssimas descrições inseridas nos delírios do próprio Orestes.

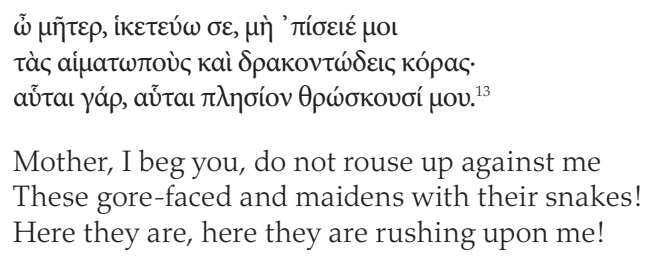

A análise de Longino é mínima. Ele identifica tais passagens como passagens que buscam atingir a audiência (ekplèxis) antes de usá-las como evidência para os poderes de visualização do próprio poeta:

\footnotetext{
${ }^{12} \mathrm{Pl} .$, Ion 535c.

${ }^{13}$ D. Chr., Or. 52.3.
} 


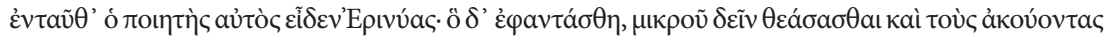
ท’

Aqui o poeta viu ele próprio as Erínias, e quase fez os ouvintes verem o que imaginou.

Para esse leitor tardio, o poeta quase logrou fazer a audiência ver as Fúrias imaginadas pela imaginação febril de Orestes porque ele próprio as imaginou ${ }^{14}$. Longino não tenta realizar uma análise técnica da passagem, mas podemos supor que é a resposta emocional do jovem, com seu uso da apóstrofe, da repetição e da linguagem fraturada, que conjura a quase visão das Fúrias pela audiência - aqui Longino fala de fazer os ouvintes quase ver (mikrou dein theasasthai). Quando tomado juntamente com sua introdução sobre a questão da visualização, na qual ele menciona a inspiração (15.1), isso soa consideravelmente próximo à análise desdenhosa de Platão sobre a cadeia de resposta imaginativa desencadeada pela recitação de Homero por Íon. Mas o que Platão estava tentando caracterizar como loucura - o rapsodo chorando enquanto, na verdade, estava usando uma coroa de ouro -, é apresentado como um dos ápices da arte poética por Longino. A ideia de loucura está presente, mas na figura de Orestes, um exemplo familiar de delírio frequentemente utilizado por filósofos.

Vamos estender as considerações sobre a passagem na peça de Eurípides: um detalhe observado por filósofos é que as visões das Fúrias por Orestes não são inteiramente imaginárias, mas na verdade, eles apontam, ele na verdade vê sua irmã Electra, mas imagina que ela é uma das Fúrias. ${ }^{15}$ Longino, naturalmente, estava lendo o texto de Eurípides, mas se aplicarmos o tipo de observação que tenho feito acerca do impacto imaginativo da linguagem vívida ao teatro, podemos especular sobre o impacto que essa passagem pode ter tido sobre a performance. Por meio das palavras de Orestes e suas reações físicas à figura que via, a audiência seria encorajada a compartilhar de suas alucinações em alguma medida e, assim, acrescentar em suas imaginações a imagem da Fúria vingativa sobre a figura perceptível da irmã amorosa. Shirley Barlow, apesar de não discutir essa passagem em particular em seu estudo Imagery of Euripides aponta um efeito bastante similar quando a reação de Menelau a Orestes torna claro o horror de sua aparência, evocando detalhes que não poderiam ser vistos por trás da máscara utilizada pelo ator. ${ }^{16}$ Voltando à passagem destacada por Longino, considerando-se o caráter e as ações de Electra na peça, em que ela admite se

${ }^{14}$ E., Or. 255-7.

${ }^{15}$ Compare os conselhos dados a oradores por Quint. Inst. 6. 2. 29-32. Ver também Webb 2009, especialmente os capítulos 4 e 5.

${ }_{16}$ S. E., M 7. 247-52 (= Long and Sedley, The Hellenistic Philosophers 40E). 
juntar ao irmão, na medida de suas capacidades, no assassinato da mãe, não é inapropriado que a audiência seja encorajada a associá-la com a imagem da Fúria manchada de sangue.

Essa passagem é particularmente interessante pela forma na qual, durante a performance, pode ser vista encorajando a sobreposição de uma imagem mental sobre a ação real no palco. Outro exemplo, observado nos escólios de Eurípides e estudado por Roos Meijering em seu trabalho pioneiro Literary and Rhetorical Theories in Greek Scholia, ${ }^{17}$ encontra-se no famoso desejo de Fedra de ser transportada a montanhas onde ela possa se envolver nas mesmas atividades que Hipólito:

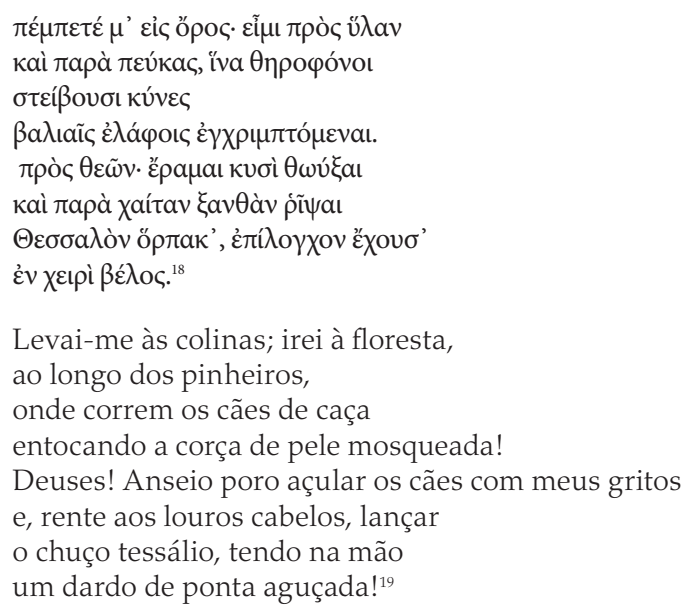

O escoliasta elogia a forma pela qual Eurípedes deu acesso, através dessa imagem, à mente de Fedra:

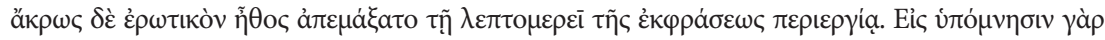

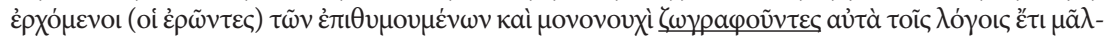

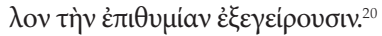

"ele imitou soberbamente o caráter da amante por meio do trabalho detalhada com a écfrase. Pois ao lembrar as coisas que desejam e pintando (zōgraphountes) essas coisas com suas palavras os amantes atiçam seu desejo a uma maior intensidade."

\footnotetext{
${ }^{17}$ Barlow 2008, 82-3.

${ }_{18}$ Trad. Joaquim Brasil Fontes

${ }^{19}$ Meijering 1987.

${ }^{20}$ E. Hipp. 215-22.
} 
Somos lembrados da forma com que Longino elogia as habilidades de Eurípides em retratar estados de paixão e loucura amorosa (como Orestes). Ambos são levados pela expressão verbal de imagens mentais que afligem os personagens. Sugeri que no caso de Orestes os ouvintes compartilham sua alucinação em certa medida, e aqui também, pode-se dizer que eles são levados não apenas a entender intelectualmente, mas também a compartilhar temporaria e parcialmente as imagens atormentadas da rainha. Como espectadores da peça, eles também estarão agudamente conscientes da divergência entre a quase incapacitada Fedra e as ações que ela evoca.

O caso de Fedra e suas ações traz um outro ponto importante sobre a écfrase em geral e a écfrase no palco em particular: écfrase e seus efeitos relacionados não são confinados a imagens estáticas. Na verdade, écfrase é frequentemente um tipo de narração vívida. Em um artigo recente, Roberto Nicolai explorou algumas implicações desse entendimento de écfrase como uma narrativa vívida em várias obras poéticas, incluindo Agamêmnon de Ésquilo. ${ }^{21}$ Aqui, Nicolai aponta a forma que o coro de Agamêmnon reconta a estória do sacrifício de Ifigênia em Aulis no início da peça. Ao escolher esse método, Ésquilo não apenas informa sua audiência desse importante pano de fundo para o ato de Clitemnestra, como também apresenta o coro como testemunha. Eu acrescentaria que a audiência é levada a dividir essa experiência conforme ela, por sua vez, testemunha o fato, levado a cabo apenas em suas imaginações. $\mathrm{O}$ ato, assim, tem uma realidade que é próxima à dos fantasmas de crianças vistos tão dramaticamente por Cassandra mais tarde na peça (vv. 1095-7 e 1215-22) - e do assassinato de Agamêmnon por Clitemnestra, que ela "vê" e relata na mesma cena nos vv. 1125-9.

Esses exemplos nos lembram de um aspecto da tragédia que é intimamente ligado à écfrase concebida como uma forma de narrativa vívida, que é a fala do mensageiro e não é por acaso que a segunda citação de tragédia encontrada em Longino vem precisamente desse tipo de passagem. Essa é a fala do mensageiro na peça perdida Faetonte. Aqui, o mensageiro primeiro cita as palavras de Hélios dizendo a Faetonte o caminho que este deveria tomar.

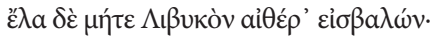

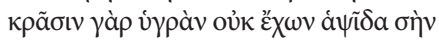

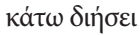

'Dirija, mas não entre no éter líbio, ele não tem umidade misturada a ele e deixará sua direção cair".

${ }^{21}$ Escólia a Euripides, ed. Schwartz, 2.32.15 (Hippolyte, 215-22) 
Em seguida, ele descreve que o garoto parte, seguido de seu pai que continua a aconselhá-lo. O que há nessa passagem para inspirar a admiração de Longino? Essa fala do mensageiro tem características em comum com a passagem de Heródoto que Longino admirava particularmente - o relato da jornada de Elefantina a Meroe, com seu uso da segunda pessoa. Aqui, também há uma combinação de detalhes concretos: os nomes dos lugares, a breve evocação da partida do garoto, o tomar das rédeas, o açoitar dos cavalos e as exortações do pai conforme este o "Dirija por ali, vire a carruagem assim, assim". Isso tudo é combinado, é claro, com nosso conhecimento de que o episódio acabará tragicamente. Mais importante, essa fala do mensageiro faz muito mais do que simplesmente informar os espectadores do acontecido, isso é, sua função não é simplesmente constativa, para emprestar o termo de Austin. Para Longino, esta passagem é outra pista para o estado mental de Eurípides: ele apenas poderia ter concebido tal imagem se sua alma tivesse estado lá e compartilhado do perigo. Sua observação nos interessa em termos de recepção de textos clássicos no período imperial. Mas o que ela pode sugerir em termos de recepção pela audiência no teatro? Sugere, eu acho, que a fala do mensageiro envolve a audiência em múltiplos pontos de vista. Neste exemplo, a audiência é brevemente assimilada a Faetonte, destinatário da fala do pai e então, compartilha a visão do espectador mais distanciado antes de ser novamente assimilada ao menino por meio das últimas exortações do pai:

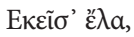

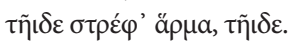

Esta passagem, admirada por Longino, pode muito bem estar por trás da reelaboração da cena em forma de pintura ficcional por Filóstrato ${ }^{22}$. Ele inicia onde termina a citação de Longino, descrevendo as consequências catastróficas. A Noite expulsando o Dia do céu, um jovem homem caindo de cabeça, seus cabelos em fogo e seu peito queimando com o calor. É notável o fato de que quando Filóstrato se apropria de temas trágicos em suas Imagines ele frequentemente se concentra em cenas que não foram levadas à cena, mas contadas pelas falas dos mensageiros.

Sua descrição das Bacantes se inicia com cenas de bacanais no Monte Citérion, tecendo motivos de duas falas separadas de mensageiros - o relato do pastor que provoca em Penteu a vontade de testemunhar as cenas e o relato final da morte de Penteu pelas mãos de sua mãe. Na descrição Hipólito, da mesma forma, o autor focaliza a morte dramática do jovem na

${ }^{22}$ Nicolai 2010, 29-45.

Let. Cláss., São Paulo, v.18, n.1, p.3-18, 2014 
praia, quando seus cavalos são aterrorizados pela besta enviada por Poseidon. As releituras efetuadas por Filóstrato são complexas, na medida em que a cena central, derivada das falas dos mensageiros, funciona como um compêndio, "simbolizando" a peça como um todo. Em sua descrição da morte de Hipólito, a ordem cronológica da narrativa é interrompida por explicações de sua causa (a falsa acusação de Fedra) e alusões às montanhas nas quais ele costumava caçar com Ártemis. Nessa imagem das Bacantes, duas cenas separadas são mencionadas: o assassinato de Penteu no Monte Citérion e o momento em que Ágave percebe que matou o próprio filho. Destas, uma foi apresentada por meio da fala de um mensageiro e a outra representada no palco. A diferença é talvez marcada por Filóstrato, que faz seu narrador distinguir os eventos na montanha e aqueles que se passam mais próximos. Em ambos os casos, Filóstrato trabalha efeitos temporais complexos com seu material. ${ }^{23}$

Suas imagens trágicas nos lembram, de fato, novamente, o impacto visual das cenas de mensageiros nas tragédias. Para o leitor de Filóstrato, assim como para o de Longino, esses eram claramente os momentos que evocavam imagens que poderiam então ser retrabalhadas e reapresentadas como se fossem pinturas. Mas qual era o efeito desses modelos de enargeia em performance? Acima de tudo, é claro que eles fazem muito mais do que informar. Eles buscam tornar a audiência testemunha de eventos trágicos. Essa observação destaca a natureza especial das falas dos mensageiros como uma das poucas partes da tragédia na qual a audiência compartilhava a perspectiva dos personagens por certa porção do tempo. Pois, no restante da peça, o espectador observa a interação entre os personagens. Obviamente isso pode levá-los a adotar momentaneamente a perspectiva de um deles, mas isso muda constantemente. Quando ouvem a fala do mensageiro, em contrapartida, eles ficam sabendo, ao mesmo tempo em que os personagens da cena, dos acontecimentos ocorridos em outro local. No Hipólito de Eurípides, por exemplo, a audiência fica sabendo ao mesmo tempo em que Teseu de que modo Hipólito encontrou a morte. Entretanto, a perspectiva da audiência é necessariamente distinta daquela dos personagens, uma vez que é, por natureza, dual. Como os personagens no palco, a audiência é transportada aos próprios eventos e transformada em testemunha, como Longino, lendo Eurípides séculos mais tarde, sentiu que era uma testemunha da corrida de carruagem, igualmente fatal, de Faetonte. Mas, assim como Longino estava ciente de que estava lendo as palavras de um poeta, a audiência no teatro também é

${ }^{23}$ Philostr., Im. 1.11 .

Let. Cláss., São Paulo, v. 18, n. 1, p.3-18, 2014 
composta de espectadores externos, assistindo aos personagens no palco recebendo e reagindo às notícias, enquanto ao mesmo tempo, reage imaginativamente por si. Isso quer dizer que a audiência no palco é tanto transportada à cena descrita como ao descrever da cena.

\section{CONCLUSÃO}

A écfrase e seus efeitos relacionados (que são amiúde praticamente sinônimos) tais como enargia ou hipotipose é, portanto, performativa em diferentes sentidos da palavra. Estreitamente ligada à fala como performance, ela é performativa na medida que tem impacto sobre a mente do ouvinte. Os testemunhos de Longino e Dião, entre outros leitores do período romano dos textos clássicos, e suas "releituras" em pinturas imaginárias por Filóstrato, nos lembram da extensão em que o envolvimento imaginativo era uma parte esperada da leitura e da audição. Podemos, eu acho, aplicar esses insights à recepção da tragédia no período clássico sem anacronismo para considerar as formas pelas quais a audiência estava envolvida e até mesmo, quase participando como testemunha dos eventos e considerar as complexidades da identificação imaginativa na tragédia como uma dimensão adicional à performance visível no palco. ${ }^{24}$

\section{REFERÊNCIAS}

Bakker, E. 2005. Pointing to the Past: From formula to performance in Homeric Poetics. Cambridge, Massachusetts: Harvard University Press.

Barlow, S. A. 2008. The imagery of Euripides : a study in the dramatic use of pictorial language. 3rd edition. London: Bristol Classical Press.

Hardie, P. 1998. "A Reading of Heliodorus' Aithiopika 3.4.1-5.2." Studies in Heliodorus, edited by R. Hunter, 19-39. Cambridge: Cambridge University Press.

Hunter, R. 1998. "The Aithiopika of Heliodorus: beyond interpretation?" In Studies in Heliodorus, edited by R. Hunter, 40-59. Cambridge, Cambridge University Press.

Meijering, R. 1987. Literary and Rhetorical Theories in Greek Scholia. Groningen: John Benjamins.

\footnotetext{
${ }^{24}$ Este é o texto de uma conferência realizada no XVIII Congresso Nacional de Estudos Clássicos, "Antiguidade: Performance \& Recepção", realizado no Rio de Janeiro de 17 a 21 de outubro de 2011. Gostaria de agradecer ao Prof. Dr. Paulo Martins o convite e à Rosângela Santoro de Souza Amato a tradução do texto para o português.
} 
Morgan, J. 1989. "The story of Knemon in Heliodoros' Aithiopika." The Journal of Hellenic Studies 109:99-113.

Morgan, J. 1991. "Reader and Audience in the Aithiopika of Heliodoros". Groningen Colloquia on the Novel 4:85-103.

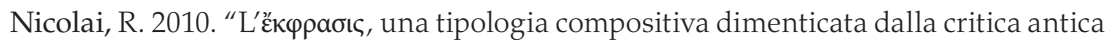
e dalla moderna". In Lo Scudo di Achille nell'Iliade: esperienze ermeneutiche a confronto. Atti della giornata di studi, Napoli, 12 maggio 2008, a cura di M. D'Acunto e R. Palmisciano, 29-45. Pisa/Roma: Fabrizio Serra editore. (= Annali dell'Istituto Universitario Orientale di Napoli v.31).

Webb, R. 2009. Ékphrasis, Imagination and Persuasion in Ancient Rhetorical Theory and Practice. Farnham: Ashgate Publishing.

Webb, R. 2013. "Les Images de Philostrate : une narration éclatée" in La trame et le tableau. Poétiques et rhétoriques du récit et de la description dans l'Antiquité grecque et latine, ed. M. Briand, 19-34. Presses Universitaires de Rennes.

Winkler, J. 1982. "The Mendacity of Kalasiris and the narrative strategy of Heliodoros' Aithiopika." Yale Classical Studies 27:93-158.

Zanker, G. 1981. "Enargeia in the Ancient Criticism of Poetry." Rheinisches Museum für Philologie 124:297-311.

Title. Ekphrasis and the stage: theatricality and reception

Abstract. One of the characteristics of ekphrasis, and the related concept of enargeia, as defined in ancient theory is its theatrical nature. The analogy with the stage is present in the stated aim of ekphrasis to "turn listeners into spectators" and, moreover, its use is associated with contexts in which the speaker is conceived as engaging in a live performance in the presence of an audience. This paper considers the implications of ekphrasis as performance for our reading of a range of texts and will pay particular attention to the use of vivid language in classical tragedy, where the images evoked by the messenger speech exist alongside the actual sights of the stage. That readers in later centuries were aware of this effect and its paradoxes is suggested by the presence among the Imagines of Philostratus of several scenes inspired by tragic messenger speeches presented as if they were the subjects of paintings. Two forms of reception are therefore considered: the reception of plays by their original Athenian audiences and the reception of the texts of those same plays by readers at later periods of antiquity.

Keywords. Ekphrasis; performativity; Greek tragedy; Messenger speeches; enargeia. 